\title{
Seasonality Effect on the Vietnamese Stock Exchange
}

\author{
Chung Tien Luu ${ }^{1}$, Cuong Hung Pham ${ }^{2} \&$ Long Pham ${ }^{3}$ \\ ${ }^{1}$ Bacgiang Garment Corporation, Vietnam \\ ${ }^{2}$ Foreign Trade University, Ho Chi Minh City Campus, Vietnam \\ ${ }^{3}$ National Economics University, Vietnam \\ Correspondence: Cuong Hung Pham, Foreign Trade University, Ho Chi Minh City Campus, \#15D5, Ward 25, Binh \\ Thanh District, Ho Chi Minh City, Vietnam.
}

Received: April 9, 2016

doi:10.5430/ijfr.v7n3p28
Accepted: May 4, 2016

Online Published: May 13, 2016

URL: http://dx.doi.org/10.5430/ijfr.v7n3p28

\begin{abstract}
The Vietnamese Stock Market is a remarkable emerging market, including the two stock markets Ha Noi and Ho Chi Minh Stock Exchange and they have been playing a very important role inVietnamese economy. More and more attention is focused on the emerging Vietnamese market, and investors have been trying to find the opportunity to achieve abnormal returns through the Vietnamese Stock Market. We name this phenomenon market efficiency a nomaly, one pattern of which is seasonality effect. In this study, the topic about the seasonality effect is chosen. We try to test the seasonality in Vietnamese Stock Market by day of the week effect, January effect and tu r n of the month effect. Deductive approach and quantitative research method are used in this thesis. To analyze seasonality effect, the data has been collected from Ho Chi Minh Stock Exchange Composite Index - VN Index and has been tested from 2006 to 2014. Hypothesis and T-test with $\alpha=0.05$ isused to test the seasonality effect. The results show that seasonal anomalies exist. The above indicates that the Vietnamese Stock Market is not fully efficient yet. Investors may have opportunities to make use of the seasonal anomalies to earn abnormal return. However, the study is based on the historical data, but the future stock price is affected by lots of factors; and like in other invested stock markets, as soon as the seasonal anomalies is certified by the public, the opportunity of making excessive return by profitable trading strategies will disappear at once.
\end{abstract}

Keywords: seasonality effect, Vietnamese stock exchange

\section{Introduction}

Vietnam is a developing country in Asia. Vietnam's GDP is rising dramatically, its foreign direct investment is rapidly increasing, and its stock market is soaring. On November 7, 2006, Vietnam was officially recognized by the international community as the 150th WTO member. Vietnam is Asia'ssecond fastest growing economy after China, and it has been forecasted that Vietnam will become the world's 17th largest economy by 2025. Although the country has been a one party communist state since 1976, Vietnam has eased restrictions on private enterprisesand has been selling off many state owned enterprises (SOEs) to the public. These offerings are not referred to as "privatization" for ideological reasons, but rather are called"equitization". In 1986, Vietnam launched the Renovation intended to transform the country from a centralized economy to a socialist-oriented market economy. These reforms have earned fruits. In 2006, Vietnam's stock market index surged $145 \%$ and in the first three months of 2007, the index rose another $60 \%$. It should be understood that the Vietnamese stock market started from a very low base of 22 listed companies at the start with a market capitalization of \$144 million.

Vietnam is a remarkable emerging market, while theVietnamese Stock Market is emerging as well. There are two stock exchanges in Vietnam, one in Hanoi and one in Ho Chi MinhCity (formerly Saigon and still called Saigon by many who live there). The Ho Chi Minh Stock Exchange was inaugurated in July 2000 with trading in two equity issues. Today, about 110 companies are listed on Vietnam's two exchanges. With the development of capitalization in Vietnam, more private investors engage in the stock market and the stock market has been playing a more and more important role in the Vietnamese economy.

\section{Literature Review}

Seasonality Effect. Seasonality effect also is called calendar effect. We can simply see from the meaning of words, it 
is about the time. Actually, the seasonality effect which includes many effects dealing with the time is one of the main patterns of the market efficiency anomalies. The people try to specify a certain period of time or a group of time to test the special phenomenon about the stock returns, then to see if any rules we can follow or any speculation opportunities we can catch. The calendar effect include: January effect, the day of the week effect, the month of the year effect, monthly effect, holiday effect, Monday effect, Weekend effect, turn of the year effect etc. Here we will give some detailed expressions about day of the week effect, January effect and semi-month effect.

Day of the Week Effect. The day of the week effect has been a hot topic for decades. The most common case is the Monday effect, meaning that the Monday's average return is significantly lower than the other days' average returns. The Fridays normally present the highest return over the most of the stock markets of the world. However, some special case appeared after some empirical studies broadly in different stock markets, for instance in some market the Tuesday effect exists instead of the Monday effect. During the past decades, many studies about the day of the week effect have been carried out. The most discussed market is US stock market, a study from Gibbons and Hess (1981) reported the US stock market from 1962 to 1978 . They found that the Monday returns are much lower than the other days' returns and the Friday returns are much higher than the other day's returns. Keim and Stambaugh (1984) used the data from US Stock Market from 1928 to 1982, and they also provided evidence that the Monday negative returns and Friday positive returns on US market.

January Effect. January effect is the most studied pattern of month of the year effect. It is defined that the January stock return is higher than the other months of the year, and it is caused normally by a significant low return in December.According to Efficient Market Hypothesis, stock prices, at any time, reveal all of the information about the market. Basically, there are three types of efficient markets: strong efficient market, semi-strong efficient market and weak-efficient market (Malkiel and Fama, 1970). The differences between these markets are clearly shown in many researches. However, in real life, efficient markets seldom exist. A great number of studies have been performed about securities market anomalies. Among them are size effects, stock split effects and seasonal effects on the price of stocks (Keim and Ziemba, 2000). Through these researches, it can be confirmed that anomalies happen regularly, which goes against the Efficient Market hypothesis. One of the anomalies that is worth mentioning in this paper is the January effect. The effect is attracting the attention of most investors as it can impact the price of securities significantly during the month of January. The January effect, known as the turn-of-the-year effect, is an effect which causes a more rapid increase in the value of securities than other months during the same year. Although the study about the January effect in Vietnam is still limited, there have been a great number of researches about this seasonal anomaly all over the world.

Turn of the Month Effect. Turn-of-the-month (TOM) effect is defined as the tendency of stocks yielding sudden change in the period between the end of this month and early next month. Turn of the Month effect is a sign of inefficiency market when the returns gained in this period is affected by the returns of other days of the month. In the literature, the last trading day of the previous month and the first four trading days of the current month (-1 to +4$)$ are usually considered as the turn of the month (TOM. In the recent decades, TOM is an anomaly mentioned in regular and seasonal reports in order to help investors to remove it from the market to avoid risk and profit from exploiting anomalies. TOM therefore seems to be a global effect, rather than the result of sampling errors or data snooping. The definition of the turn-of-the-month effect varies across the studies. The majority of studies either employ the definition of Turn-of-the-month proposed by Ariel (1987), for example Ogden (1990), Gerlach (2007) and Floros (2008), or the definition put forward by Lakonishok and Smidt (1988) like Kunken, Compton and Beyer (2003), McConnell and Wei (2008) and McGuinness and Harris (2011). If TOM effect exists, it will complement the study of the seasonal anomaly when it raises questions about the efficiency of markets and the rationale of investors. A surge profitability and overall market lasted statistically significant when switching months is inexplicable within the framework of discursive are many motivations for conducting behavioral finance research. So far, there has been relatively little research has implications for the presence (or not present) of the TOM effect in both developed and emerging markets.

\section{Research Method}

To construct the hypothesis, three ways can be chosen:

$$
\begin{array}{lll}
\text { Form } 1 & \text { Form } 2 & \text { Form } 3 \\
\text { H0: } \mu \geq \mu 0 & \text { H0: } \mu \leq \mu 0 & \text { H0: } \mu=\mu 0 \\
\text { HA: } \mu<\mu 0 & \text { HA: } \mu>\mu 0 & \text { HA: } \mu \neq \mu 0
\end{array}
$$

Where the sample mean is expressed as $\mu$ and the specified value is expressed as $\mu 0$. 
As to our study, for example, in order to test January effect, the mean return of January should be compared with the mean return of all the other months. Therefore, the two-sided hypothesis will be suitable as an instrument for our case, which can be described by the following:

$$
\begin{array}{ll}
\text { H0: } & \mu 1=\mu 2 \\
\text { HA: } & \mu 1 \neq \mu 2
\end{array}
$$

Where:

H0: the null hypothesis

HA: the alternative hypothesis

$\mu 1=$ the mean of population 1

$\mu 2=$ the mean of population 2

Our test will be performed respectively like the following descriptions: The day of the week effect

H0: $\quad \mu 1=\mu 2$

HA: $\quad \mu 1 \neq \mu 2$

$\mu 1=$ the average daily log return of the investigated day in percentage

$\mu 2=$ the average daily log return of the other weekdays in percentage

As to the day of the week effect test, as we mentioned in the theoretical part, the returns of Monday or Friday are generally found significantly different from other days. Since we don't know what kind of day of the week effect there is before we test the Vietnamese stock market, we would like to test each weekday as the investigated day. The average return of other weekdays means the mean of all the weekdays except the investigated day.

\section{The January effect}

$$
\begin{aligned}
& \text { H0: } \quad \mu 1=\mu 2 \\
& \text { HA: } \quad \mu 1 \neq \mu 2 \\
& \mu 1=\text { the average daily log return of the investigated month in percentage } \\
& \mu 2=\text { the average daily log return of rest of the months in percentage }
\end{aligned}
$$

To test the January effect in Vietnamese stock market, we compare the average daily return of January with that of all the other months of the year. Since we don't know what kind of Month-of-the-Year effect exists in Vietnamese stock market, every month has been tested whether it is significantly different from all the other months.

\section{The turn of the month effect}

$$
\text { H0: } \quad \mu 1=\mu 2
$$

HA: $\quad \mu 1 \neq \mu 2$

$\mu 1=$ the average daily log return of the turn of the month in percentage

$\mu 2=$ the average daily log return of the not turn of the month in percentage.

\section{Model for Day of the Week Effect}

This research uses data collected from Ho Chi Minh Stock exchange (HOSE), which is mainly the market index series every day ( $\mathrm{VN}$-index). The $\mathrm{VN}$-index is a blend value combined from value of all stocks' price presented on the HOSE. Actually, the index value is market weighted-average index of capitalization values. Data used in the study is gathered over the period of time from 3rd January 2006 until 31st December 2014, which is down loaded from Website of the HOSE (www.hsx.vn) via website: www.cophieu68.vn. Particularly, the material is observed over the 9-year period is the returns of each day within the weeks by using the closed value of VN-index's share price of every trading day over the mentioned period. Afterwards, the changing of the value of the index from the previous day, presented in percentage, would be calculated based on the collected raw data (2243 observations).

With the calculated data, regression models would be established to examine the impact of each day of the week on the stock returns in Vietnamese stock exchange. According to Lewis-Beck (1994) measuring performance should include empirical and theoretical concerning, so the main role of measuring activities is briefed in the following formula:

$$
X=t+e
$$


Where:

$$
\begin{array}{ll}
\text { - } & \text { X: observed score } \\
- & t \text { : true score } \\
\text { - } & \text { e: random error }
\end{array}
$$

Another way of presentation:

$$
X_{0}=X_{T}+X_{S}+X_{R}
$$

Where:

$$
\begin{array}{ll}
\text { - X0: observed score } \\
\text { - X1: true score } \\
\text { - XS: systematic error } \\
\text { - XR: random error }
\end{array}
$$

As stated in the previous point, the daily closed prices of VN-index from $03^{\text {rd }}$ January 2006 until $31^{\text {st }}$ December 2014 shall be used as resources to analyze the statistic formula.

The following formula is used to calculate daily returns

$$
\mathrm{R}_{\mathrm{t}}=\frac{\mathrm{P}_{\mathrm{t}}-\mathrm{P}_{\mathrm{t}-1}}{\mathrm{P}_{\mathrm{t}-1}} * 100 \% \text { Or } \quad \mathrm{R}_{\mathrm{t}}=\left\{\ln \left(\frac{P_{\mathrm{t}}}{P_{t-1}}\right)\right\} * 100 \%
$$

Where:

- $\quad R_{t}$ : the return over the period $t$.

- $\quad P_{t}$ : the daily closed share price index of day $t$.

- $\quad \mathrm{P}_{\mathrm{t}-1}$ : the daily closed share price index of day $\mathrm{t}-1$

Regarding to the formula, Fama (1980) has announced an original equation $R_{t}=\ln \left(P_{t}+D_{t}\right) / \ln \left(P_{t-1}\right)=E\left(R_{t}\right)+$ $\varepsilon_{t}$; the $\mathrm{P}_{\mathrm{t}}$ is the closed price of current session; $\mathrm{D}_{\mathrm{t}}$ : is the dividend of the period; $\mathrm{P}_{\mathrm{t}-1}$ is the closed price of the previous day. $\mathrm{D}_{\mathrm{t}}$ value is on ex-dividend day, so the referring price decrease by the amount of the dividend, which has no relation with the performance of the paying securities.

To test the theory, t-test method is applied in the thesis for independent samples. The dummy variables 1 and 0 ; the variable will be 1 = average return of the concerning day, and $0=$ average return on other days of the week. The value 1 will be applied from dummy variable Monday to Friday. Then the quantitative pattern is presented. The impact of the specific day of the week on the returns of $\mathrm{VN}$-index could be assessed by applying the regression model, Standard Ordinary Least Square (OLS), with dummy variables showing each day of the week. In other words, the regression model is applied to assess the theory that the returns would vary depending on different day of the week. Many empirical researches are utilized when establishing the following OLS formula:

$$
\mathrm{R}_{\mathrm{i}}=\alpha+\beta_{1} * \mathrm{MON}_{\mathrm{i}}+\beta_{2} * \mathrm{TUE}_{\mathrm{i}}+\beta_{3} * \mathrm{THU}_{\mathrm{i}}+\beta_{4} * \mathrm{FRI}_{\mathrm{i}}+\varepsilon_{\mathrm{i}}
$$

Where:

- $\quad \mathrm{R}_{\mathrm{i}}$ : The daily return of the $\mathrm{VN}$-index

- $\quad \mathrm{MON}_{\mathrm{i}}$ : dummy variable on Monday $\left(\mathrm{D} 1_{\mathrm{i}}=1\right.$ for the observation on Monday; otherwise $\left.\mathrm{D} 1_{\mathrm{i}}=0\right)$

- $\quad \mathrm{TUE}_{\mathrm{i}}$ : dummy variable on Tuesday $\left(\mathrm{D} 2_{\mathrm{i}}=1\right.$ for the observation on Tuesday; otherwise $\mathrm{D} 2_{\mathrm{i}}=0$ )

- $\quad \mathrm{THU}_{\mathrm{i}}$ : dummy variable on Thursday $\left(\mathrm{D} 3_{\mathrm{i}}=1\right.$ for the observation on Thursday; otherwise $\mathrm{D} 3_{\mathrm{i}}=0$ )

- $\quad \mathrm{FRI}_{\mathrm{i}}$ : dummy variable on Friday $\left(\mathrm{D} 4_{\mathrm{i}}=1\right.$ for the observation on Friday; otherwise $\mathrm{D} 4_{\mathrm{i}}=0$ )

- $\quad \alpha:$ is expected return on Wednesday

- $\quad \varepsilon_{\mathrm{i}}$ : is an error term, which is predicted to be independent from the rest variable

- $\quad \beta$ : represent the difference between the expected return on Wednesday and the expected returns on other days of the week

- $\beta_{1}=r_{1}-\alpha ; r_{1}$ : is the expected return on Monday

○ $\beta_{2}=r_{2}-\alpha ; r_{2}$ : is the expected return on Tuesday 


$$
\begin{aligned}
\circ & \beta_{3}=r_{3}-\alpha ; r_{3}: \text { is the expected return on Thursday } \\
\circ & \beta_{4}=r_{4}-\alpha ; r_{4}: \text { is the expected return on Friday } \\
- & \beta_{1}=\beta_{2}=\beta_{3}=\beta_{4}=0=>r_{1}=r_{2}=r_{3}=r_{4}=\alpha
\end{aligned}
$$

To prevent of the collinearity's trap, the constant of regression formula is minimized. The given formula is utilized to experiment the relative return within a particular day of the week (equal to zero or not) and to assess the variation of daily returns on different day of the week.

\section{Model for the January Effect}

The regression model is used to examine the relationship among the variables. The focus of the analysis is on the link between a dependent variable and independent variables. To be clear, the regression analysis helps determine how the value of a dependent variable changes when one of the independent variable is adjusted while the others are static. A variable that is dependent depends on other independent variables which are used to forecast the expected value of the dependent variable. While the independent variables are non-random, the dependent variable is random. Snee (1977) points out that regression analysis is a technique used for the process of forecasting, controlling and learning a mechanism from the data collected.

The monthly return is calculated using the following formula:

$$
\mathrm{R}_{\mathrm{t}}=\ln \left(\frac{\mathrm{Pt}}{\mathrm{Pt}-1}\right)
$$

in which:

Rt: the monthly return at the period of $t$

Pt: VN-Index at the period of $t$

The reasons why logarithm returns are chosen are seen to be suitable both theoretically and empirically. Under theoretical perspective, logarithmic returns are easily controlled and they can connect sub-period returns to form returns over long period. Under empirical perspective, there is strong possibility that logarithmic returns are normally distributed, which is a prerequisite for standard techniques in statistics.

To test the presence of monthly effect, in this case, January effect, the following model should be used:

$$
R_{t}=C+\beta_{2} D_{F e b}+\beta_{3} D_{M a r}+\beta_{4} D_{A p r}+\beta_{5} D_{M a y}+\beta_{6} D_{J u n}+\beta_{7} D_{J u l}+\beta_{8} D_{\text {Aug }}+\beta_{9} D_{S e p}+\beta_{10} D_{\text {Oct }}+\beta_{11} D_{\text {Nov }}+\beta_{12} D_{\text {Dec }}
$$

Whereas $\mathrm{R}_{\mathrm{t}}$ is the monthly return. $\mathrm{D}_{\mathrm{i}}$ is the dummy variable that receives the value of 1 in the month and zero otherwise. For example, $\mathrm{D}_{\mathrm{Jan}}=1$ if the return is in January and 0 otherwise, $\mathrm{D}_{\mathrm{Feb}}=1$ if the return is in February and 0 otherwise, $\mathrm{D}_{\mathrm{Mar}}=1$ if the return is in March and 0 otherwise, $\mathrm{D}_{\mathrm{Apr}}=1$ if the return is in April and 0 otherwise, $\mathrm{D}_{\text {May }}=$ 1 if the return is in May and 0 otherwise, $D_{\text {Jun }}=1$ if the return is in June and 0 otherwise, $D_{\text {Dec }}=1$ if the return is in December and 0 otherwise. The coefficients $\beta_{2}$ to $\beta_{12}$ illustrate the difference between the month of January and the $\mathrm{i}^{\text {th }}$ month with i runs from 2 to 12 .

\section{Model for the Turn of the Month Effect}

As a specific definition on TOM interval has been lacking in the literature, the method of defining TOM interval by $\mathrm{Xu}$ and McConnell (2008) has been considered for this thesis. Xu and McConnell (2008) defines the interval $[-10,+10]$, but we take into account of the average index returns by day of the month for the last five days of the previous month and the first five days of the next month $[-5,+5]$ because our sample includes some months of 16 trading days only. Hence, the last trading day of the month is day -1 , the first trading day of the month is +1 , the second day trading day of the month is day +2 , etc... Same method is applied to calculate the volumes of buy/sell/gross by day of the month but in the present study, the author decides to adopt the daily volume over each interval $[-5,+5]$ and then divide each observation of the daily volume by this average figure and average across all days of the $[-5,+5]$ interval for the entire period of 2006 to 2013. By this way, the average across all days marked -5 , the average across all days marked -4 and so on is found. Following the methods of Booth, Kallunki and Martikainen (2001), the author uses standardized returns and standardized volumes to check the first part of the previous analysis.

We use OLS method (Ordinary least square) to test for a TOM effect returns over the chosen interval. Following (Kunkel, Compton and Beyer, 2003), the following specification is used:

$$
\mathrm{R}_{\mathrm{t}}=\alpha+\beta_{1} \mathrm{D}_{\mathrm{TOM}}+\varepsilon_{\mathrm{t}}
$$

Where: 
- $\quad R_{t}$ is the index return on day $t$;

- $\quad \alpha$ is the intercept representing the mean return for the rest of the month period;

- $\quad \mathrm{D}_{\text {Том }}$ is a binary dummy variable for the TOM period; it takes the value of 1 for TOM day and 0 for non-TOM day.

- $\quad \beta_{1}$ represents the difference between the mean TOM return ad the mean ROM return;

- $\quad$ And $\varepsilon_{t}$ is the error term

If it is significant that $\beta_{1}$ is different from 0 it means that there is difference between stock return on TOM day and non-TOM days. If $\beta_{1}$ takes positive value, returns on TOM days are higher than return on non-TOM days. If $\beta_{1}$ takes positive value, returns on TOM days are higher than return on non-TOM days takes negative value, returns on TOM days are lower than return on non-TOM days. Otherwise there is no difference between return on TOM and non-TOM days.

\section{Research Results}

Results of Testing the January Effect

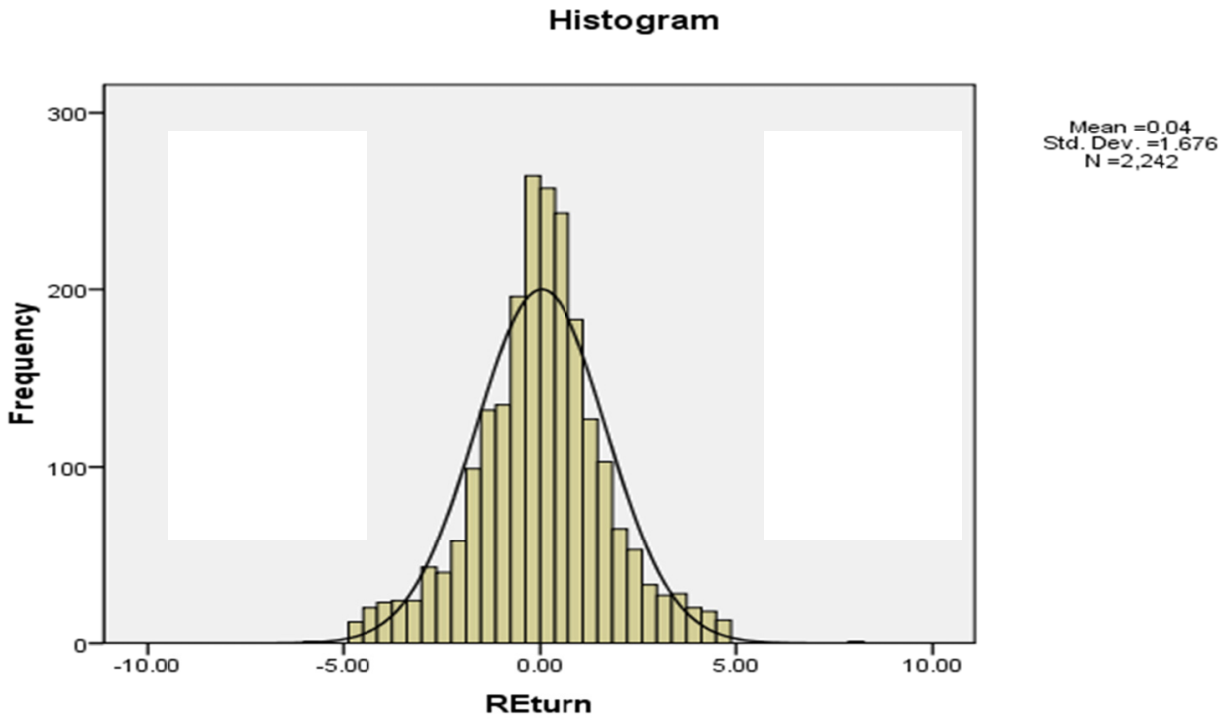

Figure 1. The daily return of VN-Index 2006-2014

As can be seen from the table and figure above, the median of closed price is lower than that average value, but the median of daily return is higher than average value. Closed price graph shows the asymmetric distribution, right tail is significantly longer and bigger than the left tail. To measure and observe the distribution of the graph we normally use skewed, which describe the asymmetric level of a distribution around the mean. That means closed price distribution concentrate on the left side of the central mean. The graph on the right hand presents a symmetric distribution of the daily return over the period $2006-2014$. The graph is quite high and narrow, that means the value is quite stable and move equally around the mean $(0.0396 \%)$. The minimum value is $-5.88 \%$ and maximum value is $8.05 \%$, the range is only $13.92 \%$.

\section{Statistic description of day of the week returns}

The basic feature of surveyed data would be presented here in the descriptive statistic part of the thesis with the main purpose of checking the main trend of data distribution over the period 2006 until the end of 2014. The Max value of VN-Index is 1170.7 and the minimum value is 235.5 during the period with 2243 daily closed prices $(\mathrm{N}=2242)$. The average value of closed price is 537.5988 while the value of daily return is $0.0396 \%$. The Median value of Closed price is 492.35 , and daily return is $0.053 \%$ 
Table 1. Daily average return over the period 2006-2014

Descriptive Statistics

\begin{tabular}{cccccccc}
\hline & $\mathrm{N}$ & Range & Minimum & Maximum & Mean & Std. Deviation & Variance \\
\hline MON & 435 & 9.48 & -4.70 & 4.78 & 0.0062 & 1.84843 & 3.417 \\
TUE & 449 & 9.58 & -4.84 & 4.74 & -0.1507 & 1.76786 & 3.125 \\
WED & 455 & 9.30 & -4.68 & 4.61 & 0.0818 & 1.56672 & 2.455 \\
THU & 455 & 10.62 & -5.88 & 4.75 & 0.0517 & 1.58845 & 2.523 \\
FRI & 448 & 12.72 & -4.68 & 8.05 & 0.2078 & 1.58370 & 2.508 \\
\hline
\end{tabular}

Within the total 2242 days collected over the period 2006-2014, and referring to the table above, there are 435 samples of daily returns on Monday, 449 on Tuesday, 455 on Wednesday and Thursday, and 448 on Friday.

The value shown in the table provides us some interesting information related to the distribution of the daily return during the days of the week. Particularly, Wednesdays over the period experienced narrowest range of returns, 9.30, while Fridays had largest range of return, 12.72, compared with other days of the weeks. However, the lowest return over the period happened on Thursdays (-5.88\%) and the highest returns happened on Fridays (8.05\%).

Mean value of daily returns is considered as one the most important aspects of the research. As can be seen from the table above, Tuesdays have the lowest and negative mean/ average value of returns, $-0.1507 \%$, it is interested that Tuesday is the only day of the week experienced the negative mean value over the period. Besides, Mondays also experienced very low mean value of daily returns $(0.0062 \%)$, just higher than only value on Tuesday. Fridays have the highest mean value of daily returns $(0.2078 \%)$ compared with those values on other days of the weeks, while Wednesday and Thursdays experienced the medial mean value of daily returns, $0.0818 \%$ and $0.0517 \%$ alternatively. However, Wednesday showed the most stable daily return with Standard deviation is 1.56672 compared with other days, while Mondays is the most various day of daily returns over the week with standard deviation value of 1.84843 , and Tuesday took the second most various position in the week with deviation value of 1.76786 .

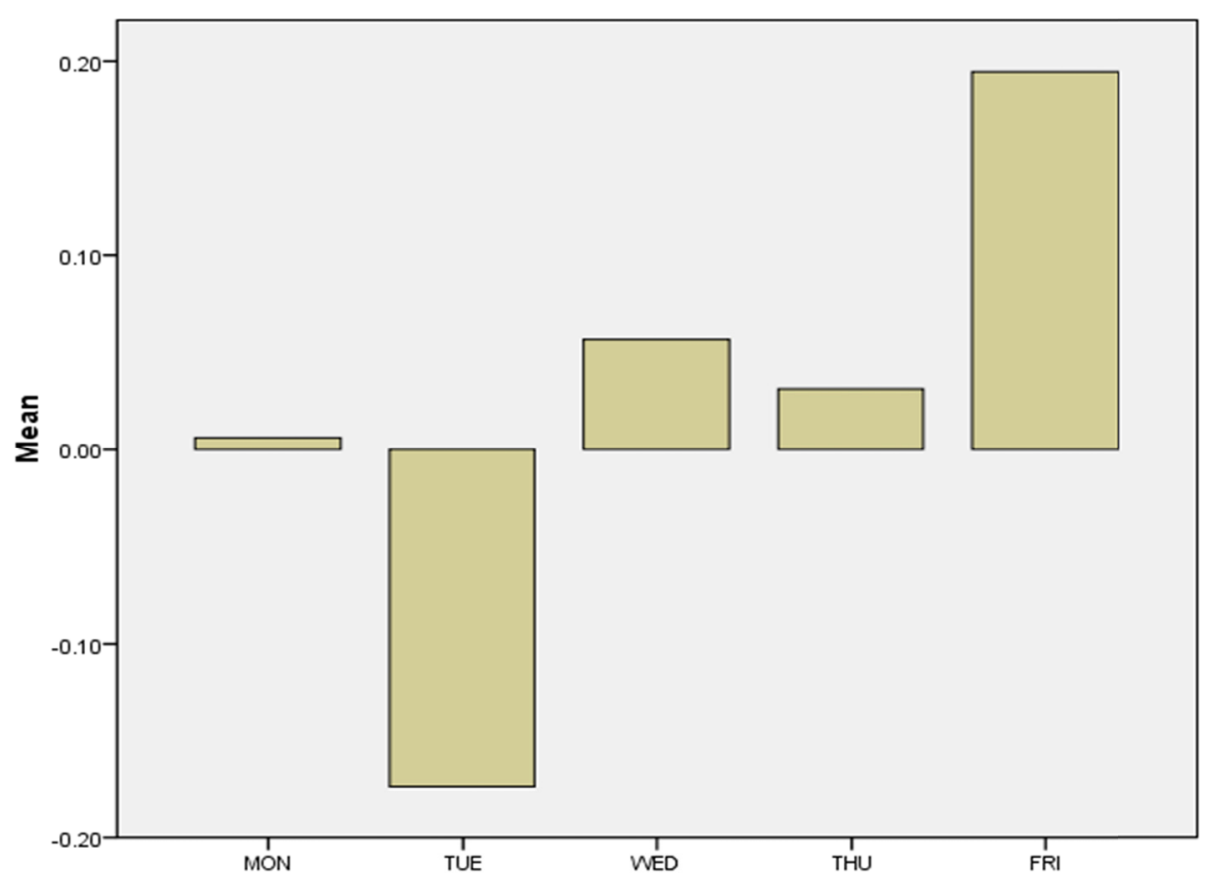

Figure 2. Average/Mean value daily return on days of the week over period 2006-2014

The Figure 2 about the average/ mean value of daily returns represents more clearly about the difference of the 
average value of daily returns between the days of the week. In other words the presented values act as key evidence for studying anomalous returns of the days during the week or effect of the day during the week.

In general, Tuesdays experienced the lowest, negative average returns of the week, while Fridays have highest mean value of returns compared with other days of the week. However, returns on Mondays have highest level of fluctuation over the week with highest value of standard deviation.

Based on the statistic description, we are able to establish the regression model for the movement trend of daily return of the stock according to the VN-Index of Vietnamese stock exchange market over the period 2006-2014.

\section{Correlation Matrix}

To establish the correlation matrix, we should base on the basic hypothesis that one variable would relate to other variable(s), which might be negative correlation or positive correlation. The Pearson correlation is one the applicable methods to estimate relationship between two variables. There are score and interval or ratio levels. In case of the researches, the presume is that Return should belong to particular day of the week (Mon- Monday, Tue-Tuesday, Wed-Wednesday, Thu-Thursday, or Fri-Friday).

As shown in the correlation matrix, the correlation level between Return variable (-0.057) and Tue variable is lowest compared with other correlations of the variables, and the value is also negative. The value of correlation matches with the discovery found above in the statistic description. Furthermore, correlation between Return and Fri variable $(+0.05)$ is positive and highest one over the concerning group. Besides, there are two negative correlations between Return and Mon and Tue, three positive correlations between Return and Wed, Thu, and Fri. However, the correlation value between Return and Thu is only 0.004. It is quite interesting that the correlation level between pairs of days of the week is nearly stable (around -0.245 to -0.252) except for correlation between Fri and Mon (0.05). In summary, the returns of the VN-Index portfolio seem to decrease at the beginning of the week and reach the bottom on Tuesday then it increase and achieve the peak of the week on Friday.

Table 2. Correlations matrix for the collected data over the period 2006-2014

\section{Correlations}

\begin{tabular}{llrrrrrr}
\hline & & \multicolumn{1}{l}{ Return } & \multicolumn{1}{l}{ Mon } & \multicolumn{1}{l}{ Tue } & \multicolumn{1}{l}{ Wed } & \multicolumn{1}{l}{ Thu } & \multicolumn{1}{c}{ Fri } \\
\hline Return & Pearson Correlation & 1 & -.010 & $-.057^{* *}$ & .013 & .004 & $.050^{*}$ \\
& Sig. (2-tailed) & & .643 & .007 & .548 & .863 & .018 \\
& $\mathrm{~N}$ & 2242 & 2242 & 2242 & 2242 & 2242 & 2242 \\
\hline Mon & Pearson Correlation & -.010 & 1 & $-.246^{* *}$ & $-.248^{* *}$ & $-.248^{* *}$ & $-.245^{* *}$ \\
& Sig. (2-tailed) & .643 & & .000 & .000 & .000 & .000 \\
& $\mathrm{~N}$ & 2242 & 2242 & 2242 & 2242 & 2242 & 2242 \\
\hline Tue & Pearson Correlation & $-.057^{* *}$ & $-.246^{* *}$ & 1 & $-.253^{* *}$ & $-.253^{* *}$ & $-.250^{* *}$ \\
& Sig. (2-tailed) & .007 & .000 & & .000 & .000 & .000 \\
& $\mathrm{~N}$ & 2242 & 2242 & 2242 & 2242 & 2242 & 2242 \\
\hline Wed & Pearson Correlation & .013 & $-.248^{* *}$ & $-.253^{* *}$ & 1 & $-.255^{* *}$ & $-.252^{* *}$ \\
& Sig. (2-tailed) & .548 & .000 & .000 & & .000 & .000 \\
& $\mathrm{~N}$ & 2242 & 2242 & 2242 & 2242 & 2242 & 2242 \\
\hline Thu & Pearson Correlation & .004 & $-.248^{* *}$ & $-.253^{* *}$ & $-.255^{* *}$ & 1 & $-.252^{* *}$ \\
& Sig. (2-tailed) & .863 & .000 & .000 & .000 & & .000 \\
& $\mathrm{~N}$ & 2242 & 2242 & 2242 & 2242 & 2242 & 2242 \\
\hline Fri & Pearson Correlation & $.050^{*}$ & $-.245^{* *}$ & $-.250^{* *}$ & $-.252^{* *}$ & $-.252^{* *}$ & 1 \\
& Sig. (2-tailed) & .018 & .000 & .000 & .000 & .000 & \\
& $\mathrm{~N}$ & 2242 & 2242 & 2242 & 2242 & 2242 & 2242 \\
\hline
\end{tabular}


Correlations

\begin{tabular}{|c|c|c|c|c|c|c|c|}
\hline & & Return & Mon & Tue & Wed & Thu & Fri \\
\hline \multirow[t]{3}{*}{ Return } & Pearson Correlation & 1 & -.010 & $-.057^{* *}$ & .013 & .004 & $.050^{*}$ \\
\hline & Sig. (2-tailed) & & .643 & .007 & .548 & .863 & .018 \\
\hline & $\mathrm{N}$ & 2242 & 2242 & 2242 & 2242 & 2242 & 2242 \\
\hline \multirow[t]{3}{*}{ Mon } & Pearson Correlation & -.010 & 1 & $-.246^{* *}$ & $-.248^{* *}$ & $-.248^{* *}$ & $-.245^{* *}$ \\
\hline & Sig. (2-tailed) & .643 & & .000 & .000 & .000 & .000 \\
\hline & $\mathrm{N}$ & 2242 & 2242 & 2242 & 2242 & 2242 & 2242 \\
\hline \multirow[t]{3}{*}{ Tue } & Pearson Correlation & $-.057^{* *}$ & $-.246^{* *}$ & 1 & $-.253^{* *}$ & $-.253^{* *}$ & $-.250^{* *}$ \\
\hline & Sig. (2-tailed) & .007 & .000 & & .000 & .000 & .000 \\
\hline & $\mathrm{N}$ & 2242 & 2242 & 2242 & 2242 & 2242 & 2242 \\
\hline \multirow[t]{3}{*}{ Wed } & Pearson Correlation & .013 & $-.248^{* *}$ & $-.253^{* *}$ & 1 & $-.255^{* *}$ & $-.252^{* *}$ \\
\hline & Sig. (2-tailed) & .548 & .000 & .000 & & .000 & .000 \\
\hline & $\mathrm{N}$ & 2242 & 2242 & 2242 & 2242 & 2242 & 2242 \\
\hline \multirow[t]{3}{*}{ Thu } & Pearson Correlation & .004 & $-.248^{* *}$ & $-.253^{* *}$ & $-.255^{* *}$ & 1 & $-.252^{* *}$ \\
\hline & Sig. (2-tailed) & .863 & .000 & .000 & .000 & & .000 \\
\hline & $\mathrm{N}$ & 2242 & 2242 & 2242 & 2242 & 2242 & 2242 \\
\hline \multirow[t]{3}{*}{ Fri } & Pearson Correlation & $.050^{*}$ & $-.245^{* *}$ & $-.250^{* *}$ & $-.252^{* *}$ & $-.252^{* *}$ & $\overline{1}$ \\
\hline & Sig. (2-tailed) & .018 & .000 & .000 & .000 & .000 & \\
\hline & $\mathrm{N}$ & 2242 & 2242 & 2242 & 2242 & 2242 & 2242 \\
\hline
\end{tabular}

**. Correlation is significant at the 0.01 level (2-tailed).

*. Correlation is significant at the 0.05 level (2-tailed).

\section{Analysis of Variance (ANOVA)}

Table 3. Analysis of variance

\begin{tabular}{rlrrrrr}
\multicolumn{8}{c}{ ANOVA $^{\mathbf{b}}$} \\
\hline 1 & Model & Sum of Squares & df & Mean Square & F & \multicolumn{1}{c}{ Sig. } \\
\hline Regression & 30.291 & 4 & 7.573 & 2.704 & $.029^{\text {a }}$ \\
& Residual & 6264.031 & 2237 & 2.800 & & \\
Total & 6294.323 & 2241 & & & \\
\hline
\end{tabular}

a. Predictors: (Constant), Fri, Mon, Tue, Thu

b. Dependent Variable: Return

As shown in the ANOVA table above the factor $\mathrm{F}$ is ratio between the variance between the dependent variable with independent variables and the variance within the variable Return. In the studying case the F ratio is 2.704 . Furthermore total squares value is 6294.323. Degree of freedom - df of regression formula is 4 therefore the mean squares is equal sum of square divided by degree of freedom (7.573).

\section{Results and Interpretations of Multiple OLS Regression Models}

The most information and result the analysis process are presented in the following Table. Furthermore, as shown in the table the given model, the variables named TUE and FRI are more significant than the rest. 
Table 4.Coefficients for regression model

\begin{tabular}{|c|c|c|c|c|c|c|c|c|}
\hline \multicolumn{9}{|c|}{ Coefficients $^{\mathrm{a}}$} \\
\hline \multirow{2}{*}{\multicolumn{2}{|c|}{ Model }} & \multicolumn{2}{|c|}{$\begin{array}{c}\text { Unstandardized } \\
\text { Coefficients } \\
\end{array}$} & \multirow{2}{*}{$\begin{array}{c}\begin{array}{l}\text { Standardized } \\
\text { Coefficients }\end{array} \\
\text { Beta }\end{array}$} & \multirow{2}{*}{$\mathrm{t}$} & \multirow{2}{*}{ Sig. } & \multicolumn{2}{|c|}{$\begin{array}{l}95 \% \text { Confidence Interval } \\
\text { for B } \\
\end{array}$} \\
\hline & & $\mathrm{B}$ & Std. Error & & & & $\begin{array}{l}\text { Lower } \\
\text { Bound }\end{array}$ & $\begin{array}{l}\text { Upper } \\
\text { Bound }\end{array}$ \\
\hline \multirow[t]{5}{*}{1} & (Constant) & .082 & .078 & & 1.042 & .297 & -.072 & .236 \\
\hline & Mon & -.076 & .112 & -.018 & -.674 & .500 & -.296 & .144 \\
\hline & Tue & -.232 & .111 & -.056 & -2.088 & .037 & -.451 & -.014 \\
\hline & Thu & -.030 & .111 & -.007 & -.271 & .786 & -.248 & .187 \\
\hline & Fri & .126 & .111 & .030 & 1.131 & .258 & -.092 & .344 \\
\hline
\end{tabular}

a. Dependent Variable: Return

Excluded Variables ${ }^{\mathrm{b}}$

\begin{tabular}{llllllll}
\hline & & Beta & & & \multirow{2}{c}{ Partial } & \multicolumn{2}{c}{ Collinearity Statistics } \\
\cline { 8 - 8 } Model & In & T & Sig. & Correlation & \multicolumn{2}{c}{ Tolerance } \\
\hline 1 & Wed & $.000^{\mathrm{a}}$ & .000 & 1.000 & .000 & & $6.925 \mathrm{E}-14$ \\
\hline
\end{tabular}

a. Predictors in the Model: (Constant), Fri, Mon, Tue, Thu

b. Dependent Variable: Return

With regards to Tuesday, the most statistically significant variable amongst explanatory ones, we find a negative ratio between Tuesday and the return. The p-value indicates a statistically significant relationship between Tuesday and the return. Furthermore, the coefficient value of Tuesday is around -0.232 that means the relative returns on Tuesday 0.232 less than returns on other days of the week relatively. The result is quite similar to output of researches performed by Truong Dong Loc (2012) in Ho Chi Minh stock market, Vietnam; Jaffe and Westerfield (1985); Dubois and Louvet (1996); Balaban at al. (2001).

Regarding to Friday, the result of the studying shown that Fridays have insignificant impact on the return yields. In particular, Fridays have positive relationship with returns. As can be seen from the table returns on FRI is 0.126, which is relatively higher than return on other days of the week. However, the p-value of Friday is 0.03 , which is quite large compared with other days and represents an insignificant relationship. But, the positive result is consistent with precious researches not only in developed markets but in emerging markets, such as Truong Dong Loc (2012) in Ho Chi Minh market, Vietnam; Kiymaz and Berument (2003) in US and Canada; Wong and Yuanto (1999) in Jakata.

Applying the data collection analyse above, and referring to regression formula:

$$
\mathrm{R}_{\mathrm{i}}=\alpha+\beta_{1} * \mathrm{MON}_{\mathrm{i}}+\beta_{2} * \mathrm{TUE}_{\mathrm{i}}+\beta_{3} * \mathrm{THU}_{\mathrm{i}}+\beta_{4} * \mathrm{FRI}_{\mathrm{i}}
$$

Where:

- $\quad \mathrm{R}_{\mathrm{i}}$ : The daily return of the $\mathrm{VN}$-index

- $\quad \mathrm{MON}_{\mathrm{i}}$ : dummy variable on Monday $\left(\mathrm{D} 1_{\mathrm{i}}=1\right.$ for the observation on Monday; otherwise $\mathrm{D} 1_{\mathrm{i}}=0$ )

- $\quad \mathrm{TUE}_{\mathrm{i}}$ : dummy variable on Tuesday $\left(\mathrm{D} 2_{\mathrm{i}}=1\right.$ for the observation on Tuesday; otherwise $\mathrm{D} 2_{\mathrm{i}}=0$ )

- $\quad \mathrm{THU}_{\mathrm{i}}$ : dummy variable on Thursday $\left(\mathrm{D} 3_{\mathrm{i}}=1\right.$ for the observation on Thursday; otherwise $\mathrm{D} 3_{\mathrm{i}}=0$ )

- $\quad \mathrm{FRI}_{\mathrm{i}}$ : dummy variable on Friday $\left(\mathrm{D} 4_{\mathrm{i}}=1\right.$ for the observation on Friday; otherwise $\mathrm{D} 4_{\mathrm{i}}=0$ )

- $\quad \alpha:$ is expected return on Wednesday

- $\quad \beta$ : represent the difference between the expected return on Wednesday and the expected returns on other days of the week

$$
\begin{aligned}
& \circ \beta_{1}=r_{1}-\alpha ; r_{1}: \text { is the expected return on Monday } \\
& \circ \quad \beta_{2}=r_{2}-\alpha ; r_{2}: \text { is the expected return on Tuesday }
\end{aligned}
$$


- $\quad \beta_{3}=r_{3}-\alpha ; r_{3}:$ is the expected return on Thursday

- $\beta_{4}=r_{4}-\alpha ; r_{4}$ : is the expected return on Friday

Finally, we achieve the regression formula as below:

$$
\mathrm{R}_{\mathrm{i}}=0.082-0.076 * \mathrm{MON}_{\mathrm{i}}-0.232 * \mathrm{TUE}_{\mathrm{i}}-0.03 * \mathrm{THU}_{\mathrm{i}}+0.126 * \mathrm{FRI}_{\mathrm{i}}
$$

\section{Results of Testing the January Effect}

After running the regression model, the following result has been produced:

Table 5. Summary statistics for the study period

\begin{tabular}{llrrrr}
\hline \multicolumn{7}{c}{ Descriptive Statistics } & & \\
\hline N & \multicolumn{7}{c}{ Minimum } & Maximum & Mean & Std. Deviation \\
\hline Jan & 9 & -.09 & .36 & .0714 & .13478 \\
\hline Feb & 9 & -.21 & .25 & .0030 & .14943 \\
\hline Mar & 9 & -.22 & .29 & .0268 & .13813 \\
\hline Apr & 8 & -.14 & .18 & .0385 & .09785 \\
\hline May & 8 & -.21 & .28 & -.0076 & .15661 \\
\hline Jun & 9 & -.05 & .09 & -.0026 & .04465 \\
\hline Jul & 9 & -.18 & .13 & -.0196 & .09164 \\
\hline Aug & 9 & -.08 & .19 & .0535 & .10270 \\
\hline Sep & 9 & -.15 & .15 & .0127 & .08639 \\
\hline Oct & 9 & -.24 & .02 & -.0287 & .08055 \\
\hline Nov & 9 & -.14 & .24 & -.0272 & .11154 \\
\hline Dec & 9 & -.08 & .19 & .0193 & .08370 \\
\hline Valid N (listwise) & 8 & & & & \\
\hline & & & & & \\
\hline
\end{tabular}

The Table 5 provides information about the minimum, maximum and average figures of the months during the period from 2006 to 2014. As can be seen from the descriptive statistics, the mean return of January was $7.14 \%$, which was the highest average monthly return that was recorded for this period of time. Meanwhile, for some other months such as May, June, July, October and November in the year, Vietnamese stock market witnessed negative returns with October suffering from the lowest average return. Therefore, it can be determined that January effect existed in the securities market of Vietnam over the period of 8 years from 2006 to 2014.

The SPSS software uses Durbin-Watson to test the conformity of the factors which affect the monthly returns. The results are shown as below:

Table 6. Durbin-Watson for the monthly returns

\begin{tabular}{rrrrrr}
\hline & R & R Square & $\begin{array}{c}\text { Adjusted R } \\
\text { Square }\end{array}$ & $\begin{array}{c}\text { Std. Error of the } \\
\text { Estimate }\end{array}$ & Durbin-Watson \\
\hline 1 & $.279^{\mathrm{a}}$ & .078 & -.028 & .11106 & 1.276 \\
\hline
\end{tabular}

a. Predictors: (Constant), Dec, Nov, Oct, Sep, Aug, Jul, Jun, May, Apr, Mar, Feb

b. Dependent Variable: Returns

The Durbin-Watson coefficient aims to investigate the incident of autocorrelation in the model. The condition is that if the coefficient is within the range of from 1 to 3, it means there is no autocorrelation phenomenon; otherwise, the phenomenon exists. According to the Table 6, the value of Durbin-Watson is 1.276, in the range of 1-3; consequently, the model has no autocorrelation phenomenon.

The results of coefficients for all of the months in the year are displayed as follows: 
Table 7. The regression results for the dependent variable the monthly return $R_{t}$

\begin{tabular}{|c|c|c|c|c|c|c|}
\hline & \multirow[t]{2}{*}{ Model } & \multicolumn{2}{|c|}{ Unstandardized Coefficients } & \multirow{2}{*}{$\begin{array}{c}\begin{array}{c}\text { Standardized } \\
\text { Coefficients }\end{array} \\
\text { Beta }\end{array}$} & \multirow[t]{2}{*}{$\mathbf{T}$} & \multirow[t]{2}{*}{ Sig. } \\
\hline & & $\mathbf{B}$ & Std. Error & & & \\
\hline \multirow[t]{12}{*}{$\overline{1}$} & (Constant) & .071 & .037 & & 1.929 & .057 \\
\hline & Feb & -.068 & .052 & -.173 & -1.306 & .195 \\
\hline & Mar & -.045 & .052 & -.113 & -.853 & .396 \\
\hline & $\overline{\mathrm{Apr}}$ & -.033 & .052 & -.083 & -.628 & .531 \\
\hline & May & -.079 & .052 & -.200 & -1.508 & .135 \\
\hline & Jun & -.074 & .052 & -.188 & -1.414 & .161 \\
\hline & Jul & -.091 & .052 & -.231 & -1.738 & .085 \\
\hline & Aug & -.018 & .052 & -.045 & -.342 & .733 \\
\hline & Sep & -.059 & .052 & -.149 & -1.122 & .265 \\
\hline & $\overline{\text { Oct }}$ & -.100 & .052 & -.254 & -1.913 & .059 \\
\hline & $\overline{\mathrm{Nov}}$ & -.099 & .052 & -.250 & -1.884 & .063 \\
\hline & $\overline{\mathrm{Dec}}$ & -.052 & .052 & -.132 & -.995 & .322 \\
\hline
\end{tabular}

The table presents the regression results for all months in the year during the period of 2006-2014. It can be seen that:

January: there is a small P-value $=5.7 \%(0.057)$, smaller than $10 \%$. Therefore, it is possible to reject the null hypothesis, or the return in January had an influence on the monthly return of investors. Furthermore, the coefficient of January is statistically significant at 5.7 percent level.

February: the P-value $=19.5 \%(0.195)$, larger than $10 \%$. Therefore, it is impossible to reject the null hypothesis, or the return in February had no impact on the monthly return.

March: the P-value $=39.6 \%(0.396)$, larger than $10 \%$. Therefore, it is impossible to reject the null hypothesis, or the return in March had no impact on the monthly return.

April: the P-value $=53.1 \%$ (0.531), larger than $10 \%$. Therefore, it is impossible to reject the null hypothesis, or the return in April had no impact on the monthly return.

May: the P-value $=13.5 \%(0.135)$, larger than $10 \%$. Therefore, it is impossible to reject the null hypothesis, or the return in May had no impact on the monthly return.

June: the P-value $=16.1 \%(0.161)$, larger than $10 \%$. Therefore, it is impossible to reject the null hypothesis, or the return in June had no impact on the monthly return.

July: there is a small P-value $=8.5 \%(0.085)$, smaller than $10 \%$. Therefore, it is possible to reject the null hypothesis, or the return in July had an influence on the monthly return of investors.

August: the P-value $=73.3 \%$ (0.733), larger than 10\%. Therefore, it is impossible to reject the null hypothesis, or the return in August had no impact on the monthly return.

September: the P-value $=26.5 \%(0.265)$, larger than $10 \%$. Therefore, it is impossible to reject the null hypothesis, or the return in September had no impact on the monthly return.

October: there is a small P-value $=5.9 \%(0.059)$, smaller than $10 \%$. Therefore, it is possible to reject the null hypothesis, or the return in October had an influence on the monthly return of investors.

November: there is a small P-value $=6.3 \%(0.063)$, smaller than $10 \%$. Therefore, it is possible to reject the null hypothesis, or the return in November had an influence on the monthly return of investors.

December: the P-value $=32.2 \%$ (0.322), larger than $10 \%$. Therefore, it is impossible to reject the null hypothesis, or the return in December had no impact on the monthly return.

It can be confirmed that the return of January, July, October and November had impacts on the overall monthly 
return of investors in Vietnam between 2006 and 2014.

\section{Conclusion}

As stated above about the efficiency of the market, and according to the principle of the "random walk" in the efficient market efficiency, the future of securities is unpredictable. Actually, the future price fluctuates in no patterns and which are independent, or they move in random walks (Brealy and Myers, 1996). However, the results of this study are similar to the previous ones conducted in the past. Particularly, according the collected data from 2006 until the end of 2014 from Vietnam stock exchange market, the study reveals that the movement of securities prices in Vietnam exchange market is abnormal or anomalous. That means there is still a chance for arbitragers to create profits based on forecasting in Vietnam stock exchange market. The day of the week effect in Vietnam market demonstrates that the future securities prices are still able to forecast in some extent.

According to the results of studies, there are chances for investors making profit in Vietnamese market by purchasing stocks on Tuesdays and selling them on the afternoon of Fridays. An individual investor would postpone planned purchasing stocks on Thursdays and Fridays until Tuesdays when the price is lowest of the week. On the other hand, the sellers would wait until Fridays to conduct the transactions when the prices get the highest point. From the results of the regression model that has been run in the precious charter, it can be concluded that the January effect had been present when the monthly returns of VN-Index during the period of 2006-2014 were taken into account. This finding about Vietnamese stock market is similar to that of other researches that have been undertaken about other developed and emerging securities markets all over the world. Based on the results, it is undoubted that the efficiency of Vietnamese stock market is weak.

\section{References}

Balaban, Ercan, Asli Bayar, \& Ozgur Berk Kan. (2001). Stock returns, seasonality and asymmetric conditional volatilityin world equity markets. Applied Economics Letters, 8, 263-268.

Brooks, C., \& Persand, G. (2001). Seasonality in Southeast Asian stock markets: Some new evidence on day-of-the-week effects. Applied Economics Letters, 8, 155-158.

Dubois, M., \& Louvet, P. (1996). The day of the week effect: The international evidence. Journal of Banking and Finance, 20, 1463-84.

Gibbons, M., \& Hess, P. (1981). Day of the week effects and asset returns. Journal of Business, 54, 579-596.

Gultekin, M. N., \& Gultekin, N. B. (1983). Stock market seasonality: International evidence. Journal of Financial Economics, 12, 469-81.

Jaffe, J., \& Westerfield, R. (1985). The week-end effect in common stock returns: The international evidence. Journal of Finance, 40, 433-454.

Keim, B. D., \& Stambaugh, R. F. (1984). A further investigation of the weekend effect in stock returns. Journal of Finance, 39, 819-840.

Keim, D. B. (1989). Trading patterns, bid-ask spreads, and estimated security returns: The case of common stocks at calendar turning points. Journal of Financial Economics, 25, 75-97.

Keim, D. B. (2006). Financial market anomalies.New Palgrave Dictionary of Economics, TheWharton School, University of Pennsylvania.Kendall, M., 1953. The analytics of economic time series, Part I: Prices. Journal of the Royal Statistical Society.

Kiymaz, Halil, \& Hakan Berument. (2003). The day of the week effect on stock olatility: International Evidence. Review of Financial Economics, 12, 363-380.

Lakonishok, J., \& Maberly, E. (1990). The weekend effect: trading patterns of individual and institutional investors. Journal of Finance, 45(1), 231-243.

Mollik, A. T., \& Bepari, M. K. (2009). Weak-form market efficiency of Dhaka Stock Exchange (DSE). Proceedings of the 22nd Australasian Finance and Banking Conference, Australian School of Business, The University of New South Wales, Sydney.

Wessel, M., Johan, W., \& Toni, V. (2006). Disappearing anomalies: a dynamic analysis of the persistence of anomalies. Applied Financial Economics, 16, 291-302.

Wong, KieAnn, \& Kusnadi Yuanto. (1999). Short-term seasonalities on the Jakarta Stock Exchange. Review of

Pacific Basin Financial Markets and Policies, 2(3), 375-398. 